\section{PAREI DE FUMAR!}

\section{Prezado Editor,}

Fui estimulado pelo meu médico a descrever como foi que deixei de fumar. Segue abaixo, o relato baseado em mensagens enviadas por e-mail a cada etapa vencida:

\section{4 horas sem fumar}

Em 28 anos, pela primeira vez estou há 24 horas sem fumar Já vi que é possível e que continuo vivo sem ele, então, agora só depende da minha força de vontade, perseverança, paciência da minha esposa, dos funcionários e amigos com meu humor (até que não está tão ruim assim, eu acho) e ao efeito da não "fissura" pelo cigarro, proporcionada pelo medicamento que me foi indicado. Obrigado pelo apoio e conselhos, e pelas unhas que a minha mulher está roendo.

\section{7dias}

Hoje estou no sétimo dia sem cigarro. Sempre contando de 24 em 24 horas. Ainda não senti todos os benefícios de ficar sem usar, porém alguns são nítidos: sem cheiro na roupa, no ambiente de trabalho, na casa, no carro, nas mãos, etc. Tenho dormido sem problemas e ainda não sonhei com ele. A garganta, de manhã, está mais limpa e o bem-estar também. Durante o dia, tenho momentos de enorme vontade de fumar, porém passa em um curto espaço de tempo: como é muito falado, a vontade passa. Tenho momentos de "estouro" "também, mas, na minha posição, o pessoal que trabalha e vive comigo já está meio acostumado; tento me conter e ter serenidade, e em certos momentos até me arrependo da minha forma de agir. $O$ jeito é ir me educando e me policiando para não engolir alguém. Muita água também ajuda. Enfim, está funcionando. Minha mulher está tentando parar sem medicamentos: em 24 horas ela já conseguiu, mas está sofrendo muito mesmo.

\section{1 dias}

Hoje completo três semanas sem cigarro. O medicamento realmente funciona, basta ter um pouco de boa vontade. Existem momentos do dia, quando passo por situações de estresse, frio, ansiedade, cafezinho, relaxamento, logo cedo, em que vem uma vontade quase que incontrolável, mas como me foi dito, em pouco tempo a "fissura" passa e o cigarro novamente cai no esquecimento. Tomar água tem me ajudado muito mais que uma balinha ou um chiclete. Ter pessoas fumando ao meu lado, ou sentir o cheiro do cigarro, estranhamente não me incomodam, e não é isso que me deixa com vontade. Sinto que se parasse de tomar o medicamento hoje, uma recaída seria fácil de ocorrer, por isso, e como não tenho tido efeitos colaterais significativos (às vezes um pouco de enjôo ou cólica, mas que podem ter outra origem - como as pressões do dia-a-dia que estamos enfrentando ultimamente) continuarei até o final do programa. Creio que até lá o meu corpo não me peça mais nicotina, alcatrão e os demais 4.998 ingredientes que compõem o cigarro. Os benefícios aos poucos têm se mostrado bem-vindos. Só de não ter que carregar um isqueiro e uma carteira de cigarros no bolso o dia todo, já é "show", imaginem então os demais... Com certeza não me arrependerei. Bom, meus caros, quem tem sofrido "um pouco" mais é a patroa. Minha esposa resolveu entrar na onda, sem auxilio medicamentoso, alguns dias após meu início. Ela estranha, porque nas duas vezes em que ficou grávida foi mais fácil - lógico que existia uma motivação muito forte neste momento. Ela tem se mantido firme (mesmo sofrendo bastante), mas está muito preocupada com a fome que tem sentido e os quilos que ganhou.

\section{9 dias}

Completo hoje 49 dias de absoluta abstinência ao cigarro. Até que não estou sofrendo muito para continuar assim. Há momentos no dia, normalmente logo cedo no carro indo para o trabalho, em que vem uma vontade louca de fumar "umzinho", mas como não tenho comigo, me seguro e a vontade passa em alguns minutos, não voltando a sentir esta "fissura" de fumar durante longos períodos. Água e chicletes me distraem, porém eficaz mesmo tem sido o tratamento medicamentoso. Minha mulher está conseguindo se segurar sem medicamento, mas é lógico que por ser mulher ela tem uma enorme vantagem sobre nós homens, mais frágeis e sensiveis à dor e ao sofrimento. Inclusive, faz dias em que ela nem sequer se lembra que fumava, porém ontem, após sofrermos um assalto à mão armada no trânsito (não aconteceu nada, além levarem meu relógio e meu rádio Nextel, pois o farol abriu e os motoristas começaram a buzinar - 9 horas da manhã, na Avenida Santo Amaro com a Juscelino Kubitschek), ela fumaria um pacote inteiro.

\section{6 dias}

O tratamento completo durou 66 dias. O resultado foi realmente fantástico. A força de vontade é necessária, mas o processo, no meu caso, não foi tão dolorido. Alguns momentos de nervosismo mais chatinho, mas passageiro. Nos primeiros dez dias depois de parar medicamento, fiz uso das dicas de um outro doutor com experiência neste processo - fui viajar / sair da rotina / passear. Sinto, agora que voltei à rotina, que isto foi bem importante, pois no dia-a-dia a vontade vem, porém é momentânea, controlável, contornável (muita água) e passa. Vou levando no "só por hoje", pois fica mais leve ir buscando a abstinência de 24 em 24 horas, e não como um nunca mais. Assim, a vitória é diária e me dá mais vontade de ganhar a batalha. O prazer de não fumar é bárbaro, glorioso e sem cheiro. Estou certo que muitos estão felizes com este resultado. As próximas grandes despesas serão grandes mesmo - engordei sete quilos, os cintos não fecham, os botões das calças estão abertos e a barriga está caindo para fora. 